\title{
The variability of summer phytoplankton in different types of lakes in North East Poland (Suwałki Landscape Park)
}

\author{
Maciej Karpowicz ${ }^{\star}$, Andrzej Górniak, Adam Więcko, Adam Cudowski \\ Department of Hydrobiology, Institute of Biology, University of Bialystok, Ciołkowskiego 1J, 15-254 Białystok, Poland, \\ e-mail: m.karpowicz@uwb.edu.pl (*corresponding author)
}

\begin{abstract}
This study describes summer phytoplankton communities in 27 lakes in the Suwałki Landscape Park (SLP) using in situ fluorescence methods. Low chlorophyll- $a$ concentrations were noted in most of the studied lakes, particularly in the deepest lakes with highest surface area. Green algae, diatoms and cryptophyta were dominant components of lake phytoplankton. Higher chlorophyll- $a$ concentrations in the shallow or more eutrophicated lakes were connected with an increase of cyanobacteria and cryptophyta concentrations as well as with a decrease in the share of diatoms inphytoplankton structure. Vertical distribution of phytoplankton in stratified lakes revealed the presence of deep chlorophyll layers just below the thermocline where the maximum concentrations of phytoplankton were up to 15 times higher than in the epilimnion zone. The deepest maximum concentration of phytoplankton was noted at a depth of 16.5 metres in Lake Jeglówek. In some lakes two or three significant increases of phytoplankton concentration in the vertical profile were observed, caused by intensive development of different algae groups.
\end{abstract}

Key words: in situ fluorescence method, Fluoroprobe, vertical distribution, deep chlorophyll layer

\section{Introduction}

Studies of the ecology of lake plankton have provided considerable information about the interactions between abiotic and biotic factors in different types of lakes (Cantin et al. 2011). Recent years have seen an increasing interest in deep chlorophyll layers in oligotrophic and mesotrophic lakes (e.g. Camacho 2006; Harrison and Smith 2011; Gauthier et al. 2014). Epilimnetic nutrient depletion allows enough light to penetrate the deeper layer where nutrient availability is often higher. These conditions would favour the growth of algae in the upper part of hypolimnion during summer stratification. New data from multi-lake field studies and experiments have supported theoretical predictions respecting the critical role of thermocline depth for phytoplankton communities (e.g. Barbiero and Tuchman 2001; Berger et al. 2007; Longhi and Beisner 2009; Cantin et al. 2011). Nowadays, in situ methods for measuring phytoplankton are indispensable tools for aquatic scientists. It is now possible to make fast and simple measurements of the vertical distribution of phytoplankton communities, which is especially important in deep lakes.

The main aim of the study was to analyse the structure of summer phytoplankton in lakes of the
Suwałki Landscape Park (SLP) using in situ fluorescence methods. We especially focused on the vertical distribution of phytoplankton communities in eight stratified lakes, but we also analysed phytoplankton structure in shallower lakes of the SLP. Furthermore, we compared measures of chlorophyll- $a$ concentration using in situ methods by the fluorescence probe and compared standard laboratory procedure using the traditional method with hot ethanol extraction and spectrometric analysis.

\section{Study area}

The SLP was created in 1976 as the first landscape park in Poland. The Park is located in the north-eastern part of Poland, in the province of Podlasie. The studied area represents a typical landscape formed during the last Vistulian glaciation. And 27 postglacial lakes comprise nearly $10 \%$ of the SLP area (JekatierynczukRudczyk et al. 2012). The studied lakes are diverse (Table 1) and include typical deep channel lakes such as Lake Hańcza, which has a maximum depth of $105.6 \mathrm{~m}$ and is the deepest lake in the Central European Lowlands; moraine lakes such as Lake Szurpiły, Lake Jaczno, 
Table 1. Morphometric characteristics of the Suwałki Landscape Park lakes (data according to Borowiak et al. 2016)

\begin{tabular}{|c|c|c|c|c|c|}
\hline Lake & Latitude & Longitude & Surface area [ha] & Maximum depth [m] & Mean depth [m] \\
\hline \multicolumn{6}{|c|}{ Deep lakes } \\
\hline Hańcza & $54^{\circ} 15,85^{\prime} \mathrm{N}$ & $22^{\circ} 48,69^{\prime} \mathrm{E}$ & 303.56 & 105.6 & 39.1 \\
\hline Szurpiły & $54^{\circ} 13,76^{\prime} \mathrm{N}$ & $22^{\circ} 53,59^{\prime} \mathrm{E}$ & 84.35 & 47.1 & 11.2 \\
\hline Jeglówek & $54^{\circ} 14,30^{\prime} \mathrm{N}$ & $22^{\circ} 53,32^{\prime} \mathrm{E}$ & 20.12 & 27.7 & 9.3 \\
\hline Kopane & $54^{\circ} 14,89^{\prime} \mathrm{N}$ & $22^{\circ} 54,30^{\prime} \mathrm{E}$ & 16.15 & 18.8 & 5.7 \\
\hline Jaczno & $54^{\circ} 16,64^{\prime} \mathrm{N}$ & $22^{\circ} 52,32^{\prime} \mathrm{E}$ & 40.64 & 25.7 & 9.8 \\
\hline Kameduł & $54^{\circ} 15,98^{\prime} \mathrm{N}$ & $22^{\circ} 51,95^{\prime} \mathrm{E}$ & 25.26 & 26.2 & 7.0 \\
\hline Kojle & $54^{\circ} 16,54^{\prime} \mathrm{N}$ & $22^{\circ} 53,52^{\prime} \mathrm{E}$ & 17.26 & 32.3 & 9.7 \\
\hline Perty & $54^{\circ} 16,44^{\prime} \mathrm{N}$ & $22^{\circ} 53,86^{\prime} \mathrm{E}$ & 19.51 & 32.6 & 7.4 \\
\hline Kluczysko & $54^{\circ} 13,99^{\prime} \mathrm{N}$ & $22^{\circ} 52,85^{\prime} \mathrm{E}$ & 3.67 & 13.8 & 5.4 \\
\hline Pogorzałek & $54^{\circ} 16,43^{\prime} \mathrm{N}$ & $22^{\circ} 50,32^{\prime} \mathrm{E}$ & 5.79 & 17.6 & 5.9 \\
\hline \multicolumn{6}{|c|}{ Shallow lakes } \\
\hline Boczniel & $54^{\circ} 15,58^{\prime} \mathrm{N}$ & $22^{\circ} 49,27^{\prime} \mathrm{E}$ & 19.17 & 3.9 & 1.3 \\
\hline Łuśnin & $54^{\circ} 16,67^{\prime} \mathrm{N}$ & $22^{\circ} 53,00^{\prime} \mathrm{E}$ & 0.47 & 3.0 & 1.5 \\
\hline Purwin & $54^{\circ} 16,83^{\prime} \mathrm{N}$ & $22^{\circ} 53,48^{\prime} \mathrm{E}$ & 1.41 & 4.3 & 2.8 \\
\hline Okrągłe & $54^{\circ} 16,01^{\prime} \mathrm{N}$ & $22^{\circ} 54,36^{\prime} \mathrm{E}$ & 15.03 & 7.4 & 4.3 \\
\hline Snouda & $54^{\circ} 15,12^{\prime} \mathrm{N}$ & $22^{\circ} 53,69^{\prime} \mathrm{E}$ & 0.49 & 4.5 & 2.0 \\
\hline Wodziłki & $54^{\circ} 14,51^{\prime} \mathrm{N}$ & $22^{\circ} 50,87^{\prime} \mathrm{E}$ & 3.73 & 5.4 & 3.1 \\
\hline Linówek & $54^{\circ} 13,44^{\prime} \mathrm{N}$ & $22^{\circ} 50,44^{\prime} \mathrm{E}$ & 2.85 & 5.9 & 2.4 \\
\hline Staw Turtul & $54^{\circ} 13,44^{\prime} \mathrm{N}$ & $22^{\circ} 48,50^{\prime} \mathrm{E}$ & - & - & - \\
\hline Purwinek & $54^{\circ} 16,87^{\prime} \mathrm{N}$ & $22^{\circ} 53,92^{\prime} \mathrm{E}$ & 0.44 & 3.3 & 1.5 \\
\hline Ślepe & $54^{\circ} 17,12^{\prime} \mathrm{N}$ & $22^{\circ} 55,67^{\prime} \mathrm{E}$ & - & - & - \\
\hline Postawelek & $54^{\circ} 16,99^{\prime} \mathrm{N}$ & $22^{\circ} 56,62^{\prime} \mathrm{E}$ & 3.35 & 4.0 & 2.0 \\
\hline Udziejek & $54^{\circ} 15,24^{\prime} \mathrm{N}$ & $22^{\circ} 53,29^{\prime} \mathrm{E}$ & 7.01 & 6.9 & 3.3 \\
\hline Gulbin & $54^{\circ} 15,60^{\prime} \mathrm{N}$ & $22^{\circ} 53,99^{\prime} \mathrm{E}$ & 7.38 & 9.1 & 3.5 \\
\hline Błędne & $54^{\circ} 14,94^{\prime} \mathrm{N}$ & $22^{\circ} 52,24^{\prime} \mathrm{E}$ & 2.74 & 4.8 & 1.9 \\
\hline Jeglóweczek & $54^{\circ} 14,20^{\prime} \mathrm{N}$ & $22^{\circ} 52,78^{\prime} \mathrm{E}$ & 1.81 & 8.3 & 3.1 \\
\hline Przechodnie & $54^{\circ} 16,73^{\prime} \mathrm{N}$ & $22^{\circ} 55,50^{\prime} \mathrm{E}$ & 23.89 & 5.4 & 3.1 \\
\hline Krejwelek & $54^{\circ} 16,31^{\prime} \mathrm{N}$ & $22^{\circ} 55,12^{\prime} \mathrm{E}$ & 5.50 & 8.8 & 2.8 \\
\hline
\end{tabular}

Lake Perty and Lake Kojle, which have varied coastlines formed by the melting of dead ice blocks (Jekatierynczuk-Rudczyk et al. 2014); and shallow polymicitc lakes.

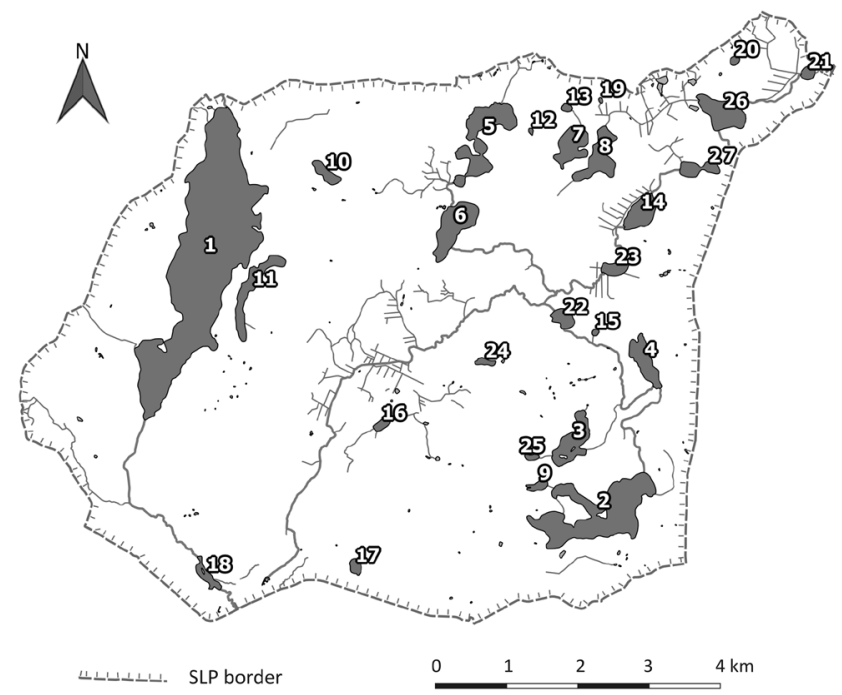

Fig. 1. Location of studied lakes in Suwałki Landscape Park. Description as in Table 1

\section{Methods}

Measurements of phytoplankton communities and temperature of water of different types of lakes in the Suwałki Landscape Park (SLP) were made close to the deepest point of the lakes during summer stagnation (July 2015) using a FluoroProbe (bbe-Moldaenke, Kiel, Germany). Continuous fluorometric measurements of chlorophyll in the profile of stratified lakes were made every few centimeters from the lake surface down to $30 \mathrm{~m}$. The FluoroProbe spectrofluorometer provides in situ measurements of total chlorophyll- $a$ and also determines algae classes on the basis of identifying differences among fluorescence excitation spectra. The FluoroProbe uses five light-emitting diodes (LED; operating at $470,525,570,590$, and $610 \mathrm{~nm}$ ) to excite the accessory pigments associated with photosystem II antenna system (Kring et al. 2014). Changes in the resulting chlorophyll- $a$ emission allows for fluorometric estimation of algal classes based on differences in species and class-dependent peripheral antenna pigments (Beutler et al. 2002). The FluoroProbe identifies the phytoplankton class based on precalibrated excitation and emission 
spectra "fingerprints" programmed into the instrument, viz. (1) Green algae: Chlorophyta and Euglenophyta; (2) Cyanobacteria: phycocyanin (PC)-rich cyanobacteria; (3) Diatoms: Heterokontophyta, Haptophyta, and Dinophyta; and (4) Cryptophytes: Cryptophyta and the phycoerythrin (PE)-rich cyanobacteria. The fingerprints that characterize the separate groups are derived from the fluorometric analysis of laboratory cultures of phytoplankton groups of interest (Beutler et al. 2002). Measurements are corrected for background chromophoric dissolved organic matter (CDOM) present in natural waters that can interfere with excitation and emission spectra (Twiss 2011). The CDOM correction is referred to as a yellow substance correction and is characterized by a sixth LED operating at $370 \mathrm{~nm}$ in addition to the other LEDs (Kring et al. 2014). Constant measurements in the profile of stratified lakes were made every few centimeters depth. Vertical distribution of phytoplankton communities was analysed in eight thermally stratified lakes. Figures 3 and 4 show the averaged values of parameters for each metre depth. Phytoplankton communities in shallow lakes were measured at a depth of 1 metre. Finally, the studied lakes were divided into groups based on the phytoplankton structure as well as trophic conditions and hydrology.

Additionally, chlorophyll- $a$ concentration was determined by the laboratory spectrophotometric method with ethanol extraction. Samples were filtered on GF/C filters and extracted with boiling $90 \%$ ethanol (Lorenzen 1965; Nusch 1980).

\section{Results}

Total chlorophyll- $a$ concentration in shallow lakes ranged from 4.28 to $27.0 \mu \mathrm{g} \mathrm{dm}^{-3}$ (Table 2). The highest total concentration of chlorophyll $a$ was found in the epilimnion of Lake Kluczysko $\left(43.9 \mu \mathrm{g} \mathrm{dm}{ }^{-3}\right)$. Green algae, bluegreen algae, diatoms and cryptophyta were present in all lakes. The most important component of phytoplankton in shallow lakes was green algae (4.56 $\pm 2.8 \mu \mathrm{g} \mathrm{dm}^{-3}$ ). Green algae were the dominant group of phytoplankton in lakes: Łuświn, Purwin, Snouda, Pur-

Table 2. Average composition of phytoplankton (total concentration, green algae, bluegreen, diatom and cryptophyta) and yellow substance concentration in epilimnion zone of ten stratified lakes and in the seventeen shallow lakes of the Suwałki Landscape Park

\begin{tabular}{|c|c|c|c|c|c|c|}
\hline Lake & $\begin{array}{c}\text { green algae } \\
{\left[\mu \mathrm{g} \mathrm{dm}^{-3}\right]}\end{array}$ & $\begin{array}{c}\text { bluegreen } \\
{\left[\mu^{\prime} \mathrm{dm}^{-3}\right]}\end{array}$ & $\begin{array}{l}\text { diatoms } \\
{\left[\mu \mathrm{g} \mathrm{dm}^{-3}\right]}\end{array}$ & $\begin{array}{l}\text { cryptophyta } \\
{\left[\mu \mathrm{g} \mathrm{dm}^{-3}\right]}\end{array}$ & $\begin{array}{c}\text { Total } \\
{\left[\mu \mathrm{g} \mathrm{dm}^{-3}\right]}\end{array}$ & $\begin{array}{c}\text { yellow substances } \\
{\left[\mu \mathrm{g} \mathrm{dm}^{-3}\right]}\end{array}$ \\
\hline \multicolumn{7}{|c|}{ Stratified lakes } \\
\hline Hańcza & 2.48 & 0.27 & 0.35 & 0.92 & 4.02 & 0.58 \\
\hline Szurpiły & 2.80 & 0.75 & 1.06 & 1.52 & 6.13 & 0.33 \\
\hline Jeglówek & 0.90 & 0.38 & 1.32 & 0.30 & 2.90 & 0.38 \\
\hline Kopane & 5.40 & 2.10 & 2.86 & 1.17 & 11.53 & 0.41 \\
\hline Jaczno & 1.27 & 0.10 & 1.51 & 0.12 & 3,00 & 0.14 \\
\hline Kameduł & 1.21 & 0.38 & 0.88 & 0.27 & 2.74 & 0.36 \\
\hline Kojle & 0.73 & 0.22 & 0.80 & 0.59 & 2.34 & 0.35 \\
\hline Perty & 1.33 & 0.07 & 0.90 & 1.01 & 3.31 & 0.53 \\
\hline Kluczysko & 5.71 & 23.83 & 4.21 & 10.21 & 43.96 & 0.66 \\
\hline Pogorzałek & 4.94 & 6.44 & 4.49 & 1.15 & 17.02 & 0.96 \\
\hline \multicolumn{7}{|c|}{ Shallow lakes } \\
\hline Boczniel & 1.33 & 0.76 & 1.44 & 0.76 & 4.29 & 1.25 \\
\hline Łuśnin & 6.54 & 0.15 & 0.77 & 3.24 & 10.7 & 0.81 \\
\hline Purwin & 5.10 & 1.11 & 2.47 & 0.01 & 8.69 & 1.02 \\
\hline Okrągłe & 2.62 & 1.83 & 3.53 & 1.08 & 9.06 & 0.75 \\
\hline Snouda & 6.03 & 0.32 & 1.06 & 0.24 & 7.65 & 0.71 \\
\hline Wodziłki & 2.82 & 1.33 & 3.24 & 2.45 & 9.84 & 1.28 \\
\hline Linówek & 4.02 & 4.24 & 6.21 & 1.25 & 15.72 & 4.13 \\
\hline Staw Turtul & 2.84 & 0.23 & 2.89 & 1.30 & 7.26 & 1.16 \\
\hline Purwinek & 8.17 & 0.27 & 5.29 & 1.02 & 14.75 & 0.66 \\
\hline Ślepe & 1.58 & 0.50 & 1.86 & 0.77 & 4.71 & 0.37 \\
\hline Postawelek & 5.14 & 0.88 & 3.13 & 1.99 & 11.14 & 0.98 \\
\hline Udziejek & 12.92 & 4.58 & 6.23 & 3.28 & 27.01 & 0.28 \\
\hline Gulbin & 3.33 & 0.91 & 1.65 & 1.68 & 7.57 & 1.06 \\
\hline Błędne & 3.82 & 1.43 & 0.92 & 0.43 & 6.60 & 1.54 \\
\hline Jeglóweczek & 3.09 & 0.67 & 0.49 & 1.07 & 5.32 & 1.24 \\
\hline Przechodnie & 5.22 & 1.33 & 0.13 & 2.36 & 9.05 & 0.52 \\
\hline Krejwelek & 2.90 & 4.51 & 2.93 & 2.53 & 12.87 & 0.79 \\
\hline
\end{tabular}


Table. 3. The average and standard deviation (s.d.) of summer chlorophyll- $a$ concentrations $\left(\mu \mathrm{gm}^{-3}\right)$ in epilimnion of separated groups of lakes in the Suwalki Landscape Park

\begin{tabular}{|c|c|c|c|c|c|c|c|}
\hline Group & Lakes & & green algae & bluegreen & diatoms & cryptophyta & Total \\
\hline \multirow{2}{*}{ I } & \multirow{2}{*}{ Hańcza, Kojle, Perty } & avg. & 1.51 & 0.19 & 0.68 & 0.84 & 3.22 \\
\hline & & s.d. & 0.88 & 0.1 & 0.29 & 0.22 & 0.84 \\
\hline \multirow{2}{*}{ II } & \multirow{2}{*}{ Jaczno, Jeglówek, Kameduł, Szurpiły } & avg. & 1.54 & 0.4 & 1.19 & 0.55 & 3.69 \\
\hline & & s.d. & 0.85 & 0.26 & 0.27 & 0.64 & 1.62 \\
\hline \multirow{2}{*}{ III } & \multirow{2}{*}{ Kluczysko, Kopane, Pogorzałek, Udziejek } & avg. & 7.24 & 9.23 & 4.44 & 3.95 & 24.88 \\
\hline & & s.d. & 3.79 & 9.88 & 1.38 & 4.28 & 14.24 \\
\hline \multirow{2}{*}{ IV } & \multirow{2}{*}{ Gulbin, Krejwelek, Okrągłe, Postawelek, Przechodnie } & avg. & 3.84 & 1.89 & 2.27 & 1.92 & 9.93 \\
\hline & & s.d. & 1.24 & 1.51 & 1.38 & 0.57 & 2.07 \\
\hline \multirow{2}{*}{$\mathrm{V}$} & \multirow{2}{*}{$\begin{array}{l}\text { Boczniel, Błędne, Jeglóweczek, Ślepe, Linówek, Łuśnin, } \\
\text { Purwin, Purwinek, Snołda, Wodziłki, Staw Turtul }\end{array}$} & avg. & 4.12 & 1,00 & 2.42 & 1.14 & 8.68 \\
\hline & & s.d. & 2.13 & 1.16 & 1.87 & 0.95 & 3.81 \\
\hline
\end{tabular}

winek, Postawelek, Udziejek, Gulbin, Błędne, Jeglóweczek and Przechodnie (Table 2). Bluegreen algae strongly dominated only in Lake Kluczysko $\left(23.8 \mu \mathrm{g} \mathrm{dm}^{-3}\right)$, but they constituted an important group of phytoplankton in lakes: Krejwelek, Pogorzałek, Linówek and Udziejek (Table 2). Diatoms were the dominant group of phytoplankton in Lake Linówek and Lake Boczniel (Table 2).
In the shallow lakes cryptophyta had the the lowest share in shaping phytoplankton communities.

The studied lakes were divided into 5 groups ( $\mathrm{Ta}$ ble 3) based on the phytoplankton structure and trophic conditions. The first group were deep, mesotrophic lakes with low phytoplankton biomass in the epilimnion (Hańcza, Kojle, Perty). The second group represents
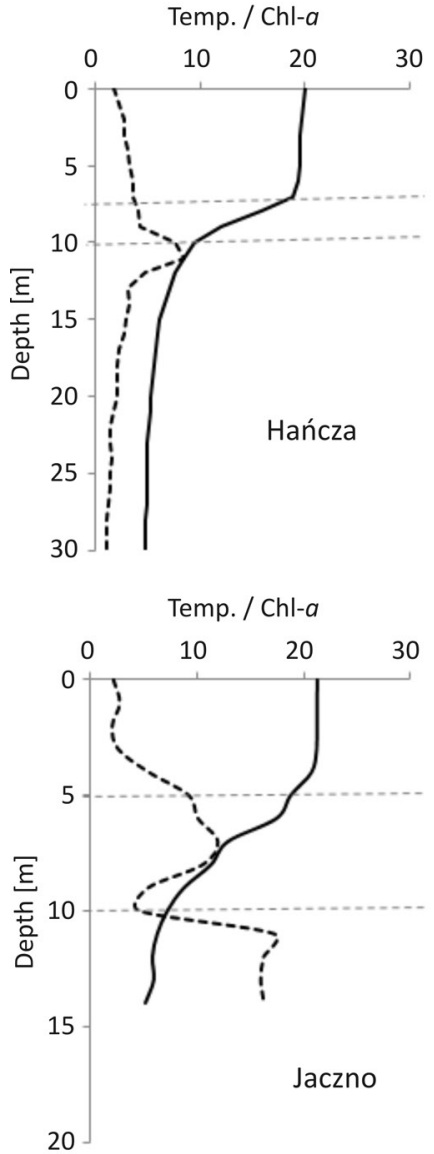

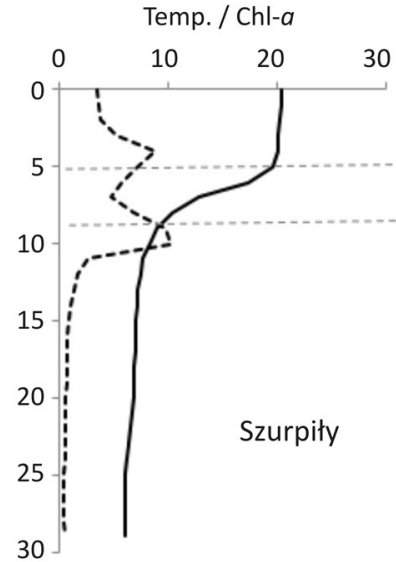

Temp. / Chl-a

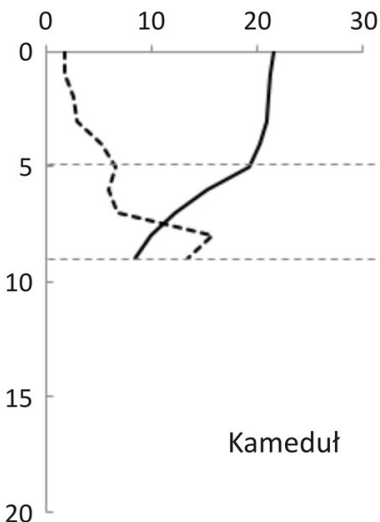

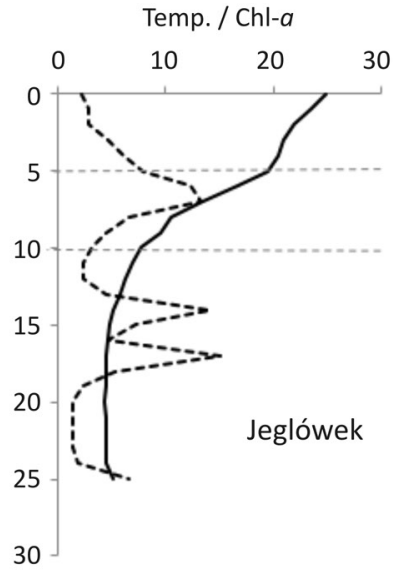

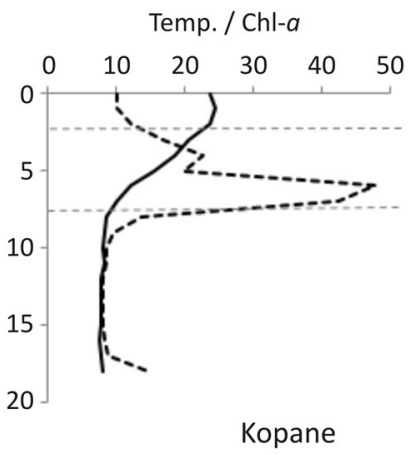

Temp. / Chl-a
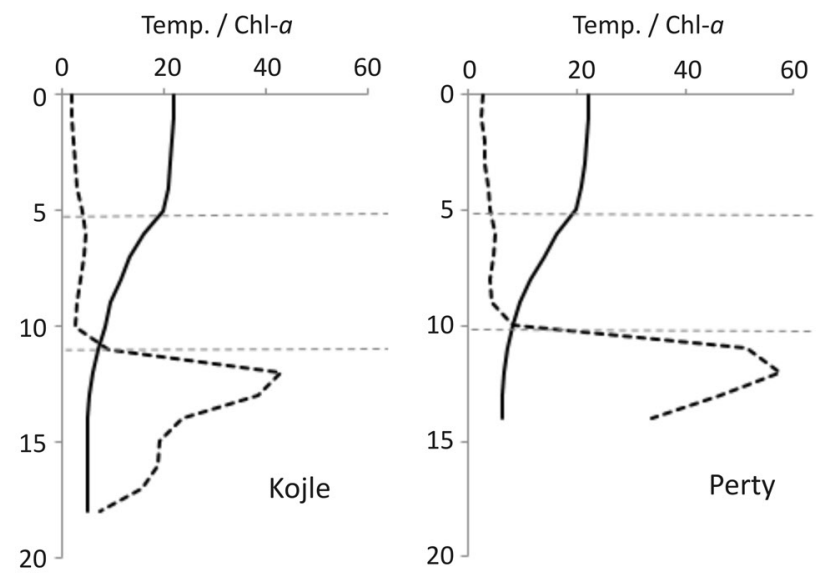

— Temperature $\left[{ }^{\circ} \mathrm{C}\right]$

--- Chlorophyll- $a$ concentration $\left[\mu \mathrm{g} \mathrm{dm}^{-3}\right]$

Fig. 2. Vertical profiles of temperature (solid line, ${ }^{\circ} \mathrm{C}$ ) and total phytoplankton (chlorophyll- $a, \mu \mathrm{dm}^{-3}$ ) (dotted line) in eight stratified lakes of the Suwałki Landscape Park. Horizontal dotted lines show the thermocline zone 
deep meso-eutrophic lakes with an increased share of green algae in phytoplankton structure (Table 3). The third group were eutrophic lakes with the highest chlorophyll-a concentration with increased bluegreen algae in the phytoplankton structure. The fourth group were eutrophic lakes located along the course of the River Szeszupa. The final group were small and shallow eutrophic lakes with a higher share of green algae in their phytoplankton structure (Table 3 ).

Total chlorophyll- $a$ concentration in the epilimnion zone of the eight stratified lakes ranged between $1.46-12.2 \mu \mathrm{g} \mathrm{dm}^{-3}$. The lowest values of chlorophyll- $a$ in the epilimnion zone were observed in Lake Hańcza and Lake Kojle (Fig. 2). However, in all thermally stratified lakes a deep-water algal maximum was observed in the upper part of the hypolimnion and in the thermocline zone (Fig. 2), where the concentration of phytoplankton was much higher than in the epilimnion zone. The deepest maximum concentration of phytoplankton was noted in Lake Jeglówek a at depth of 16.5 metres (Fig.
2). The maximum concentration of phytoplankton in the hypolimnion zone was up to 15 times higher than in the epilimnion zone of the stratified lakes (i.e. Lake Perty, Lake Kojle).

In some lakes two or three significant increases of phytoplankton concentration were observed in the vertical profile (Fig. 2) caused by different groups of algae (Fig. 3). In Lake Jaczno the first significant increase of phytoplankton in the upper metalimnion was caused by diatoms. A second large increase of phytoplankton in the upper hypolimnion was caused by cryptophytes (Fig. 3). In Lake Szurpiły the first increase of phytoplankton concentration was observed in the lower epilimnion zone, due to a greater abundance of green algae and diatoms. The maximum concentration of phytoplankton in the upper hypolimnion zone of Lake Szurpily resulted from an increased presence of cryptophyta and diatoms (Fig. 3), while in Lake Jeglówek three significant increases in phytoplankton biomass were observed, where the maximum density of diatoms was recorded at a depth of 7
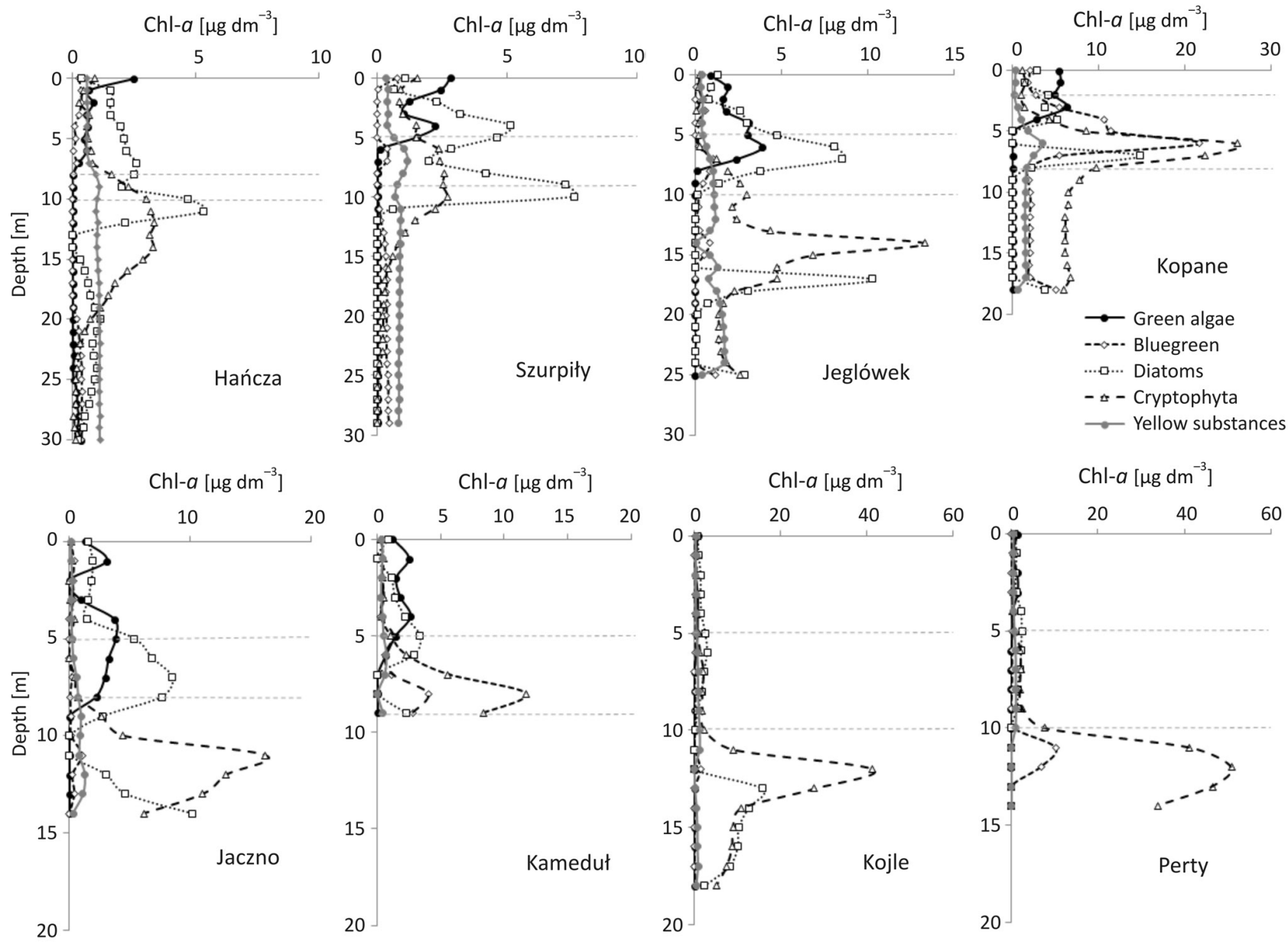

Fig. 3. Vertical profiles of algae (green algae, bluegreen, diatoms, cryptophyta) distribution in eight stratified lakes of the Suwałki Landscape Park. Horizontal dotted lines show the thermocline zone 

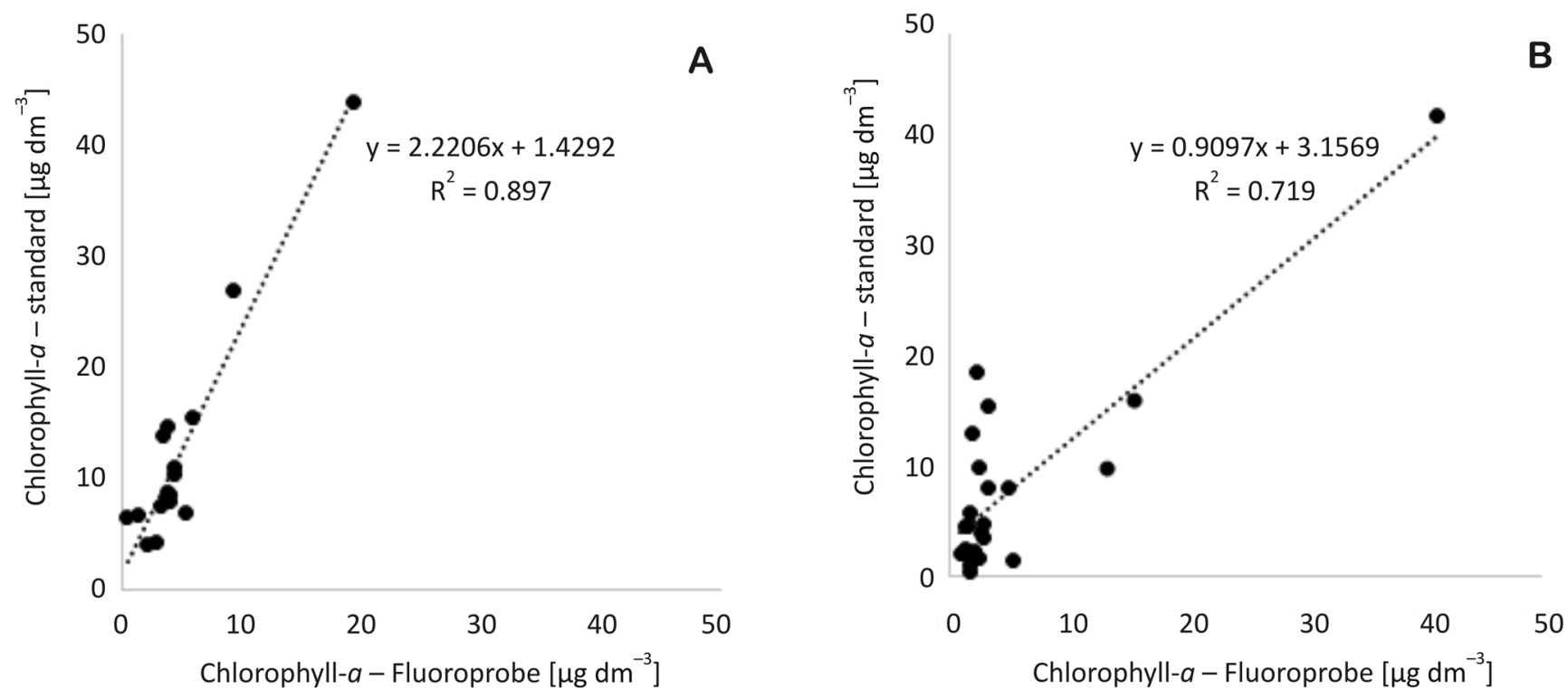

Fig. 4. Comparison of in situ measures of total chlorophyll- $a$ concentration using the bbe- FluoroProbe with the standard laboratory procedure with ethanol extraction in shallow lakes (A) and deep lakes (B) in the Suwałki Landscape Park

and $16.5 \mathrm{~m}$, while the maximum density cryptophytes was found at a depth of $14 \mathrm{~m}$ (Fig. 3). To summarize, different groups of algae reached maximum density at different depths in most stratified lakes. The exception is Lake Kopane where the maximum density of cryptophyta, diatoms, green algae and bluegreen algae was recorded in the thermocline zone (Fig. 3).

The dominant groups of phytoplankton in stratified lakes were diatoms and cryptophyta, reaching the highest density in the deeper zones. They frequently reached maximum densities at various depths, especially in Lake Jeglówek and Lake Jaczno (Fig. 3). Green algae were found in the highest density in the epilimnion zone of stratified lakes. Bluegreen algae formed a minor component of phytoplankton in most stratified lakes (Fig. 3).

Rapid in situ measurements of total chlorophyll$a$ concentration using the bbe FluoroProbe were compared with the standard laboratory procedure with ethanol extraction. The results obtained by the both methods in the deep lakes were similar (Fig. 4B). However, in the shallow lakes the values of chlorophylla concentration obtained by the standard procedure were generally twice as high as the results obtained with the in situ measurements (Fig. 4A).

\section{Discussion}

The structure of phytoplankton of most lakes indicated a good ecological status with low phytoplankton biomass and a low share of cyanobacteria. A distinctive feature of Lake Linówek is the high CDOM concentration which is typical of humic waters. A previous study revealed high bacteria concentration and high primary production in Lake Linówek (Jekatierynczuk-Rudczyk et al. 2014). This may be evidence of humo-eutrophication processes (Górniak 1996; Górniak and Karpowicz 2014) in Lake Linówek.

Vertical distribution of phytoplankton in stratified lakes revealed the presence of deep chlorophyll layers in the upper part of hypolimnion and in the thermocline zone. The maximal concentration of phytoplankton in the hypolimnion zone was up to 15 times higher than in the epilimnion zone. Deep chlorophyll layers are a common phenomenon in oligotrophic and mesotrophic lakes (Camacho 2006). Low trophic conditions associated with vertical stratification and promoting epilimnetic summer nutrient depletion allow enough light to penetrate to the metalimnion and upper hypolimnion (Reynolds 1992), where nutrient availability is often higher. These conditions would favour the growth of certain algae in the upper part of hypolimnion (St. Amand and Carpenter 1993). Increased algal densities below the thermocline have been related not only to nutrient availability (Fee et al. 1977; Fasham et al. 1985), but also to zooplankton grazing (Richerson et al. 1978) and grazing-related increased vertical particle flux (Sarnelle 1999).

Deep chlorophyll layers in the stratified lakes of the Suwałki Landscape Park were caused by the maximum concentrations of diatoms and cryptophytes. Deep chlorophyll layers formed by diatoms and cryptophytes have been reported for many temperate lakes of North America, Central and Northern Europe (e.g. Jackson et al. 1990; Camacho et al. 2001; Stoermer 
2005). Some authors have reported the formation of such deep chlorophyll layers by cyanobacteria (e.g. Padisák et al. 1998; Kasprzak et al. 2000) as well as other algae (e.g. Vincent et al. 1980; Zvikas 2005). Cyanobacteria in our study were an important component of the deep chlorophyll layer only in Lake Kopane. The results of our study indicated that different groups of algae frequently reached maximum density at different depths using different niches in the vertical profiles of lakes. It is possible that the hypolimnion maxima of phytoplankton can be affected by the direct inflow of ground water with a specific chemical composition that can stimulate the growth of selected species of algae. The probability that direct groundwater inflow to SLP lakes can affect several layers is very high in situations where craton structures of postglacial sediments exist, such as in the Lithuanian Lakeland (Mitręga et al. 1983).

To date, the phytoplankton of Lake Hańcza and Lake Szurpiły has been the most intensively studied (Spodniewska 1978; Hutorowicz and NapiórkowskaKrzebietke 2008; Grabowska et al. 2006; JekatierynczukRudczyk et al. 2012). Phytoplankton biomass indicates the mesotrophic and oligotrophic character of these two lakes (Hutorowicz and Napiórkowska-Krzebietke 2008; Jekatierynczuk-Rudczyk et al. 2012). In the years 19732009 , the main components of phytoplankton biomass were dinoflagellates, cyanoprokaryotes or diatoms (Jekatierynczuk-Rudczyk et al. 2012). The dominant species in 1999-2001 was the cyanophyte Aphanocapsa incerta (Hutorowicz and Napiórkowska-Krzebietke 2008), after which the diatoms of the genus Cyclotella were the most important group with a domination of Cyclotella radiosa (Grunow) Lemmerm. (Jekatierynczuk-Rudczyk et al. 2012). The results of our study confirm a low biomass of phytoplankton in Lake Hańcza and Lake Szurpiły with a domination of diatoms and cryptophytes.

\section{Conclusion}

In situ methods for measuring phytoplankton are indispensable tools for aquatic scientists and lake monitoring. Besides the total concentration of chlorophyll$a$, it is also possible to discover the relationship between different groups of phytoplankton in the whole water column. The structure of phytoplankton in most of the lakes in the Suwałki Landscape Park indicated a good ecological status with low chlorophyll- $a$ concentration and a low share of cyanobacteria. In all thermally stratified lakes a deep-water algal maximum was observed where the concentration of phytoplankton was much higher than in the epilimnion zone. Generally, different groups of algae reached maximum density at different depths using various vertical niches in the thermal stratified lakes.

\section{References}

Barbiero R.P., Tuchman M.L., 2004, The deep chlorophyll maximum in Lake Superior, J. Great Lakes Res. 30(Suppl. 1): $256-268$.

Berger S.A., Diehl S., Stibor H., Trommer G., Ruhenstroth M., Wild A., Weigert A., Jager C.G., Striebel M., 2007, Water temperature and mixing depth affect timing and magnitude of events during spring succession of the plankton, Oecologia (Berl.) 150(4): 643-654.

Beutler M., Wiltshire K.H., Meyer B., Moldaenke C., Lüring C., Meyerhöfer M., Hansen U.-P., Dau, H., 2002, A fluorometric method for the differentiation of algal populations in vivo and in situ, Photosynth. Res. 72(1): 39-53.

Borowiak D., Nowiński K., Grabowska K., 2016, A new bathymetric survey of the Suwałki Landscape Park lakes, Limnol. Rev. 16(4): 185-197.

Camacho A., Vincente E., Miracle M.R., 2001, Ecology of Cryptomonas at the chemocline of a karstic sulphate-rich lake, Mar. Freshwater Res. 52: 805-815.

Camacho A., 2006, On the occurrence and ecological features of deep chlorophyll maxima (DCM) in Spanish stratified lakes, Limnetica 25(1-2): 453-478.

Cantin A., Beisner B.E., Gunn J.M., Prairie Y.T., Winter J.G., 2011, Effects of thermocline deepening on lake plankton communities, Can. J. Fish. Aquat. Sci. 68(2): 260-276.

Fasham M.J.R., Platt T., Irwin B., Jones K., 1985, Factors affecting the spatial pattern of the deep chlorophyll maximum in the region of the Azores front, Prog. Oceanogr. 14: 129-165.

Fee E. J., 1976, The vertical and seasonal distribution of chlorophyll in lakes of the Experimental Lakes Area, northwestern Ontario: Implications for primary production estimates, Limnol. Oceanogr. 21(6): 767-783.

Gauthier J., Prairie Y.T., Beisner B.E., 2014, Thermocline deepening and mixing alter zooplankton phenology, biomass and body size in a whole-lake experiment, Freshwater Biol. 59(5): 998-1011.

Górniak A., 1996, Substancje humusowe i ich rola w funkcjonowaniu ekosystemów słodkowodnych (Humus substances and their role in the freshwater ecosystems functioning), Diss.Univ.Vars. 445, Wydaw. UW, Warszawa, 151 pp. (in Polish).

Górniak A., Karpowicz M., 2014, Development of crustacean plankton in a shallow, polyhumic reservoir in the first 20 years after impoundment (northeast Poland), Inland Waters 4(3): 311-318.

Grabowska M., Konecka U., Górniak A., 2006, Summer phytoplankton of lakes in Suwałki Landscape Park, Pol. J. Environ. Stud. 15(5d): 553-556.

Harrison J.W., Smith R.E.H., 2011, Deep chlorophyll maxima and UVR acclimation by epilimnetic phytoplankton, Freshwater Biol. 56(5): 980-992.

Hutorowicz A., Napiórkowska-Krzebietke A.,2008, Zbiorowiska fitoplanktonu w jeziorze Hańcza (Phytoplanktom communities in Hańcza Lake), [in:] Kozłowski J., 
Poczyński P., Zdanowski B. (eds), Środowisko i ichtiofauna jeziora Hańcza (Enironment and ichtiofauna of Lake Hańcza) Wydaw. IRS, Olsztyn: 93-102 (in Polish).

Jackson L.S., Stockner J.G., Harrison P.J., 1990, Contribution of Rhizosolenia eriensis and Cyclotella spp. to the deep chlorophyll maximum of Sproat lake, British Columbia, Canada, Can. J. Fish. Aquat. Sci. 47(1): 128-135.

Jekatierynczuk-Rudczyk E., Grabowska M., Ejsmont-Karabin J., Karpowicz M., 2012, Assessment of trophic state of four lakes in the Suwałki Landscape Park (NE Poland) based on the summer phyto- and zooplankton in comparison with some physicochemical parameters, [in:] Wołowski K., Kaczmarska I., Ehrman J., Wojtal A.Z. (eds), Phycological Reports: Current advances in algal taxonomy and its applications: phylogenetic, ecological and applied perspective, Inst. Bot. PAN, Kraków: 205-225.

Jekatierynczuk-Rudczyk E., Zieliński P., Grabowska M., Ejsmont-Karabin J., Karpowicz M., Więcko A., 2014,The trophic status of Suwałki Landscape Park lakes based on selected parameters (NEPoland), Environ. Monit. Assess. 186(8): 5101-5121.

Kasprzak P., Gervais F., Adrian R., Weiler W., Radke R., Jager I., Riest S., Siedel U., Schneider B., Bohme M., Eckmann R., Walz N., 2000, Trophic characterization, pelagic food web structure and comparison of two mesotrophic lakes in Brandenburg (Germany), Int.. Rev. Hydrobiol. 85: 167-189.

Kring S.A., Figary S.E., Boyer G.L., Watson S.B., Twiss M.R., 2014, Rapid in situ measures of phytoplankton communities using the bbe FluoroProbe: evaluation of spectral calibration, instrument intercompatibility, and performance range, Can. J. Fish. Aquat. Sci. 71(7): 1087-1095.

Longhi M.L., Beisner B.E., 2009, Environmental factors controlling the vertical distribution of phytoplankton in lakes, J. Plankton Res. 31(10): 1195-1207.

Lorenzen C.J., 1965, A note on the chlorophyll and phaeophytin content of the chlorophyll maximum, Limnol. Oceanogr. 10(3): 482-483.

Mitręga J., Paczyński B., Płochniewski Z., 1993, Wody podziemne Suwalszczyzny (Groundwaters of Suwałki
Region). Prz. Geol. 41(8): 569-574 (in Polish, English summary).

Nusch E.A., 1980, Comparison of different methods for chlorophyll and phaeopigment determination, Ergeb. Limnol. 14: 14-36.

Padisák J., Krienitz L., Scheffler W., Koschel R., Kristiansen J., Grigorszky I., 1998, Phytoplankton succession in the oligotrophic Lake Stechlin (Germany) in 1994 and 1995, Hydrobiologia 370: 179-197.

Reynolds C.S., 1992, Dynamics, selection and composition of phytoplankton in relation to vertical structure in lakes, Ergebn. Limnol. 35: 13-31.

Richerson P.J., Lopez M., Coon T., 1978, The deep chlorophyll maximum layer of Lake Tahoe, Verh. Int. Ver. Limnol. 20: 426-433.

Sarnelle O., 1999, Zooplankton effects on vertical particle flux: testable models and experimental results, Limnol. Oceanogr. 44(2): 357-370.

Spodniewska I., 1978, Phytoplankton as the indicator of lake eutrophication. I. Summer situation in 34 Masurian Lakes, Ekol. Pol. 26(1): 53-70.

St. Amand A., Carpenter S. R., 1993, Metalimnetic phytoplankton dynamics, [in] Carpenter S.R., Kitchell J.F. (eds), The trophic cascade in lakes, Cambridge Univ. Press, Cambridge: 210-224.

Stoermer E.F., Emmert G., Julius M.L., Schelske C.L., 1996, Paleolimnological evidence of rapid recent changes in Lake Eire's trophic status, Can. J. Fish. Aquat. Sci. 53(6): 1451-1458.

Twiss M.R., 2011, Variations in chromophoric dissolved organic matter and its influence on the use of pigment-specific fluorimeters in the Great Lakes, J. Great Lakes Res. 37(1): 124-131.

Vincent W.F., Goldman C.R., 1980, Evidence for algal heterotrophy in Lake Tahoe, California-Nevada, Limnol. Oceanogr. 25(1): 89-99.

Zvikas A., 2005, Structure of microorganism communities and peculiarities of their activities in gypsum karst lakes of northern Lithuania [Summary of PhD Thesis], Institute of Botany, Vilnius University, Vilnius, $37 \mathrm{pp}$. 